ISSN: 1410-8917

Jurnal Kimia

Sains \&

Aplikasi

e-ISSN: 2597-9914
Jurnal Kimia Sains dan Aplikasi Journal of Scientific and Applied Chemistry

Journal homepage: http://ejournal.undip.ac.id/index.php/ksa

\title{
Effect of methyl substituent on the solubility of 1,4-benzoquinone derivatives in $\mathrm{n}$-octanol/water system
}

\author{
Siti Mariyah Ulfa ${ }^{a},{ }^{*}$, Fath Dwisari ${ }^{a}$, Ade Cintya Sally ${ }^{a}$, M. Farid Rahman ${ }^{a}$ \\ ${ }^{\text {a }}$ Chemistry Department, Faculty of Science, Brawijaya University, Jl. Veteran Malang, Malang, 65145, Indonesia \\ *Corresponding author: ulfa.ms@ub.ac.id \\ https://doi.org/10.14710/jksa.23.5.142-146
}

\section{Article Info}

Article history:

Received: $28^{\text {th }}$ October 2019 Revised: $26^{\text {th }}$ April 2020

Accepted: $27^{\text {th }}$ April 2020

Online: $31^{\text {st }}$ May 2020

Keywords:

1,4-benzoquinone;

decarboxylation;

bioavailability; coefficient

partition

\begin{abstract}
The solubility of the compound is a crucial task for new drug design. Quinone is a promising candidate to develop as a new drug. In this research, the synthesis of 1,4benzoquinone derivatives, that is, 2-(5-bromoamyl)-3,5-dimethyl-1,4benzoquinone (2a) and 2-(5-bromoamyl)-5-methyl-1,4-benzoquinone (2b) were carried out by decarboxylation and insertion reaction of alkyl bromides. The product $\mathbf{2 a}$ and $\mathbf{2 b}$ are purified using $\mathrm{SiO}_{2}$ gel column chromatography and analyzed by UVVisible, FT-IR, and NMR. The yield of $2 \mathrm{a}$ is $13.75 \%$, and $\mathbf{2 b}$ is $4.04 \%$. The solubility of $\mathbf{2 a}$ and $\mathbf{2 b}$, expressed by $\log \mathrm{P}$, is measured in the $\mathrm{n}$-octanol/water $(3: 7(\mathrm{v} / \mathrm{v}))$ system by the shake flask method. The $\log P$ of $2 \mathrm{a}$ and $\mathbf{2 b}$ are 2.99 and 1.36 , respectively. It is showed that the $\log \mathrm{P}$ of $\mathbf{2 a}$ is higher compared to $\mathbf{2 b}$. The presence of two methyl substituents on the quinone ring of 2 a supports the increase of hydrophobicity of the compound in the $\mathrm{n}$-octanol/water system.
\end{abstract}

\section{Introduction}

Quinone is ubiquitous natural compounds which have fascinating chemical and biological properties. One of their derivatives is 2-isopropyl-5-methyl-1,4benzoquinone (known as thymoquinone/TQ), which is the major constituent in Nigella sativa seed essential oil. The structure of the TQ is depicted in Figure 1. There are many reports about the activity of TQ such as antiinflammatory, antidiabetic, and anticancer [1, 2, 3, 4]. The problem arising from TQ for drug candidates is the rapid elimination and relatively slower absorption when consumed by oral [5]. These properties are related to the structure-activity relationship (SAR) of TQ and the receptor in the body [6]. The presence of the alkyl group is responsible for increasing the hydrophobicity or lipophilicity. By modifying hydrophobicity, the penetration of the compound to the cell membrane is easier. Then, the binding of the compound with the receptor is increased. The addition of alkyl halide, methoxy, and the ionic group is reported to increase the lipophilicity of quinone derivatives based on in-silico approach $[7,8,9]$.<smiles>CC1=CC(=O)C(C(C)C)=CC1=O</smiles>

Figure 1. Structure of thymoquinone

Modification of structure should follow Lipinski rules, i.e., the molecular weight is under 500, hydrogen donor less than 5, and hydrogen acceptor not more than 10 [10]. Several structural modifications have been reported. Antonenko et al. [11] reported the addition of an alkyl group with an ionic counterpart. In this report, alkyl substituent increased the lipophilicity, and the phosphonic ion connected with terminal carbon increased the ion channel. The insertion of cationic phosphonyl derivatives into 1,4-benzoquinone was smoothly penetrated the mitochondrial cell wall and increased the antioxidant effect [11]. Following that result, our groups reported the addition of alkyl bromine into 1,4-benzoquinone framework and predicted the activity for anticancer, antidiabetic, and antioxidant using macromolecules model protein by in-silico 
approach [7, 8]. The result showed that the presence of alkyl bromide or methoxy in the quinone ring increases the activity against the macromolecules model. The invitro design by the shake flask method to evaluate the solubility of 1,4-benzoquinone was also reported [9, 12]. The longer alkyl carbon insertion in the quinone skeleton has also increased the hydrophobicity and promote the solubility.

The solubility of the drug candidate expressed by Log P should not exceed 5 points [10]. The Log P-value can be determined by the shake flask method. This method involves the mixing of aqueous solutions of the compounds with the organic phase, such as, n-octanol and allowing the system to reach equilibrium. When equilibrium was formed, the concentration remaining in the water phase or the organic phase was measured by high-performance liquid chromatography (HPLC). Log P is determined by equation 1 as follows [13].

$$
\log \mathrm{P}=\log \frac{\text { Coctanol }}{C \text { water }}=\log \frac{A o / V o}{A w / V w}
$$

In this work, the synthesis of 2-(5-bromoamyl)3,5-dimethyl-1,4-benzoquinone (2a) and 2-(5bromoamyl)-5-methyl-1,4-benzoquinone (2a) is proposed. Compound $\mathbf{2 a}$ and $\mathbf{2} \mathbf{b}$ have different methyl substituents, either in the position or in the amount of methyl group. It is expected that the different methyl substituent position influences the solubility of the compounds.

\section{Methodology}

\subsection{Material and instrumentation}

The reagent is an analytical grade, otherwise stated. The 2,6-dimethyl-1,4-benzoquinone (1a), 2-methyl1,4-benzoquinone (1b), and bromohexanoic acid were purchased from Sigma Aldrich, Singapore. The silver(I) nitrate $\left(\mathrm{AgNO}_{3}\right)$, ammonium persulfate $\left(\left(\mathrm{NH}_{4}\right)_{2} \mathrm{~S}_{2} \mathrm{O}_{8}\right)$, acetonitrile, $\mathrm{Na}_{2} \mathrm{HPO}_{4}, \quad \mathrm{NaH}_{2} \mathrm{PO}_{4}$, n-octanol, and chloroform were purchased from Merck, Singapore. The solvent $\mathrm{n}$-hexane and ethyl acetate were purchased from a local vendor and used after distillation.

The instrumentation used is $\mathrm{pH}$ meter Schott Gerate/CG 820, UV-Visible Shimadzu 1600, FT-IR Shimadzu 8400S, HPLC Shimadzu LC-20AD Prominence connected with C18 Shim-Pack CLC-ODS column (4.6 $\mathrm{mm} \times 250 \mathrm{~mm}$, I.D $5 \mu \mathrm{m}$ ) and UV Shimadzu SPDM20A detector. The NMR used is JEOL ECS-400, using $\mathrm{CDCl}_{3}$ as a solvent.

\subsection{Experiment}

2.2.1. Synthesis of 2-(5-bromoamyl)-3,5-dimethyl1,4-benzoquinone (2a) and 2-(5-bromoamyl)5-methyl-1,4-benzoquinone (2b)

Synthesis of $\mathbf{2 a}$ and $\mathbf{2 b}$ is according to the previous report [11, 12]. The starting material 3,5-dimethyl-1,4benzoquinone (1a) ( $2 \mathrm{mmol}, 0.544 \mathrm{~g}$ ) was mixed with bromohexanoic acid (2.1 mmol, $0.82 \mathrm{~g}$ ), $\mathrm{AgNO}_{3}(1 \mathrm{mmol}$, $0.54 \mathrm{~g})$ and added with $14 \mathrm{~mL}$ of acetonitrile: water (2:1 $\mathrm{v} / \mathrm{v})$, heated and stirred until $90^{\circ} \mathrm{C}$. A solution of $\left(\mathrm{NH}_{4}\right)_{2} \mathrm{~S}_{2} \mathrm{O}_{8}(2 \mathrm{mmol})$ in $6 \mathrm{~mL}$ water added dropwise to the solution and continue to stir for 2 hours at the subjected temperature. The obtained crude product was purified using a silica gel column with n-hexane: chloroform $(7: 3(\mathrm{v} / \mathrm{v}))$. The obtained product $2 \mathrm{a}$ was characterized using Shimadzu $8400 \mathrm{~S}$ Fourier Transform-Infrared (FT-IR), UV-Visible Shimadzu 1600, and ${ }^{1} \mathrm{H}-\mathrm{NMR}$ JEOL ECS-400. A similar procedure for the synthesis of 2-(5-bromoamyl)-5-methyl-1,4benzoquinone (2b) was performed by replacing the starting material into 2-methyl-1,4-benzoquinone (1b) in the same mol ratio.

\subsubsection{Solubility test of $2-(5$-bromoamyl)-3,5- dimethyl-1,4-benzoquinone (2a) and 2-(5- bromoamyl)-5-methyl-1,4-benzoquinone (2b)}

A phosphate buffer solution was prepared by mixing $\mathrm{NaH}_{2} \mathrm{PO}_{4} \cdot \mathrm{H}_{2} \mathrm{O}(0.1 \mathrm{M})$ and $\mathrm{Na}_{2} \mathrm{HPO}_{4}(0.1 \mathrm{M})$ until the $\mathrm{pH}$ is 7.4 measured by pH meter Schott Gerate/CG 820. The buffer is subjected as the water phase, then saturated with n-octanol to obtain hydrophilic phase (water phase). The hydrophobic phase was obtained by saturating the n-octanol solution with $\mathrm{pH} 7.4$ aqueous buffer (octanol phase). Each partition was taken with a ratio volume of $\mathrm{n}$-octanol:water $(3: 7(\mathrm{v} / \mathrm{v}))$. Both solutions were standing for at least 24 hours for complete saturation [13]. Each compound, 2a, and $\mathbf{2 b}$ were dissolved in the $n$-octanol phase to prepare a 10 mM solution. The partition was conducted by mixed 7 $\mathrm{mL}$ of water phase with $3 \mathrm{~mL}$ of $\mathrm{n}$-octanol phase then shaken for one hour at room temperature. After equilibration, n-octanol and water phase were separated, and each of them was injected for analysis using HPLC. The HPLC was performed by injected $2 \mu \mathrm{L}$ of each partition (flow rate of $0.5 \mathrm{~mL} / \mathrm{min}$ at $37^{\circ} \mathrm{C}$ ).

\section{Results and Discussion}

\subsection{Synthesis of 2-(5-bromoamyl)-3,5-dimethyl-1,4- benzoquinone (2a) and 2-(5-bromoamyl)-5- methyl-1,4-benzoquinone (2b)}

The synthesis of $\mathbf{2 a}$ and $\mathbf{2 b}$ is described in Scheme $\mathbf{1}$. Bromoalkylation reaction is proposed by decarboxylation and substitution reaction. The reaction is to proceed at $\mathrm{pH}$ 1-3. Synthesis of $\mathbf{2 a}$ is easily performed and obtained in higher yield compared to $\mathbf{2 b}$ (Table $\mathbf{1}$ ). This is probably by the presence of two methyl substituents at $\mathrm{C}-2$ and C-6 in 1,4-benzoquinone derivatives 1a. The electronic induction effect from methyl substituent into $\pi$ aromatic conjugated system, such as in benzoquinone, is suppressed by the acidity of the reaction solution then the nucleophilic addition is preferable. A similar result was reported by Mbiya et al. [14] for the reaction of quinone with thiol, which was conducted at $\mathrm{pH}$ below 5.5. Furthermore, the presence of methyl on C-2 and C6 on 1a accidentally promotes the substitution of bromoalkyl on $0-/ p$ - position. The presence of carbonyl in $\mathrm{C}-1$ and $\mathrm{C}-4$, either in $\mathbf{1 a}$ or $\mathbf{1 b}$ may not influence in the product selectivity. 


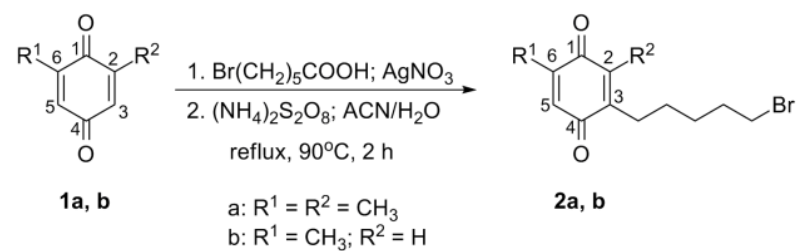

Scheme 1. Bromoalkylation reaction of 1,4benzoquinone

The physical properties of $\mathbf{2 a}$ and $\mathbf{2 b}$ are depicted in Table 1. Compound $\mathbf{2 a}$ and $\mathbf{2 b}$ have lower polarity compared to $\mathbf{1 a}$ and $\mathbf{1 b}$, which analyzed from the retention factor (Rf) elucidated using hexane/chloroform solvent on $\mathrm{SiO}_{2}$ plate. This is showed that the addition of bromoamyl group on the benzoquinone ring (C-3) reduces the polarity of the compound. Further analysis using FTIR showed the increasing intensity of the $\mathrm{CH}-$ $\mathrm{sp}^{3}$ stretching in $2925-2927 \mathrm{~cm}^{-1}$, and an additional medium intensity peak is detected in $686 \mathrm{~cm}^{-1}$ accounted for $\mathrm{C}-\mathrm{Br}$ functional group (supplementary 1: S1a, S1b) [15]. Analysis of the ultraviolet spectrum of $\mathbf{2 a}$ and $\mathbf{2 b}$ showed the bathochromic shift. All the data is similar to the previous report for 1,4-benzoquinone derivative [12].

Table 1. Physical properties and spectral data of compound $\mathbf{2 a}$ and $\mathbf{2 b}$

\begin{tabular}{|c|c|c|c|c|c|}
\hline 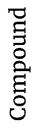 & $\begin{array}{l}\text { Shape } \\
\text { and color }\end{array}$ & $\begin{array}{c}\text { Yield } \\
(\%)\end{array}$ & $\begin{array}{l}\text { Retention } \\
\text { factor (Rf) }\end{array}$ & $\begin{array}{l}\text { Wavenumber } \\
(\mathrm{cm}-1)^{\mathrm{b}}\end{array}$ & $\begin{array}{l}\text { Wavelength } \\
(\mathrm{nm})^{\mathrm{c}}\end{array}$ \\
\hline $2 a$ & Yellow oil & 13.75 & 0.78 & $\begin{array}{l}2927 \text { (sharp-intense; } \\
\text { CH-sp3) } \\
686 \text { (medium; C-Br) }\end{array}$ & 257 \\
\hline $2 b$ & Yellow oil & 4.04 & 0.75 & $\begin{array}{c}2925 \text { (sharp-intense; } \\
\text { CH-sp3) } \\
686 \text { (medium; C-Br) }\end{array}$ & 250 \\
\hline
\end{tabular}

a. Thin Layer Chromatography (TLC) analysis using hexane-chloroform $(6: 4(\mathrm{v} / \mathrm{v}))$

b. Fourier Transform Infra-Red (FTIR) analysis using $\mathrm{NaCl}$ plate

c. Ultraviolet-Visible (UV-Vis) analysis in octanol

The analysis of proton NMR was carried out based on the chemical shift and the coupling constant of each proton (Figure 2, Table 2, the NMR spectrum is depicted in Supplementary 2: S2a, S2b). The characteristics of compound $2 \mathrm{a}$ can be detected by the appearance of the peaks at chemical shift $3.40 \mathrm{ppm}(\mathrm{t}, 2 \mathrm{H}, J=6.8 \mathrm{~Hz})$ which is identified as methylene protons bounded to 5bromoamyl carbon atoms. The presence of bromine as an electronegative atom causes the protons to be less protected and shifted to the greater chemical shifts. Six methylene protons bound to the quinone ring with the sequence $-\mathrm{CH}_{2}-\mathrm{CH}_{2}-\mathrm{CH}_{2}$ - are shown with a multiplex spectrum at a chemical shift of $1.45(\mathrm{~m}, 4 \mathrm{H}, J=7.4 ; 7.8$ $\mathrm{Hz})$ and $1.87 \mathrm{ppm}(\mathrm{q}, 2 \mathrm{H}, J=6.8 ; 7.4 \mathrm{~Hz})$. The methylene proton, which is bound directly to the quinone, is measured at $2.46 \mathrm{ppm}(\mathrm{t}, 2 \mathrm{H}, J=7.8 \mathrm{~Hz})$. Two methyl groups bound to the quinone appear as a singlet at $\delta=$ $2.04 \mathrm{ppm}(\mathrm{s}, 6 \mathrm{H})$ with integration for six protons. The analysis for compound $\mathbf{2 b}$ is similar to $\mathbf{2 a}$, except the appearance of two singlets at $\delta=6.56 \mathrm{ppm}(\mathrm{s}, 1 \mathrm{H})$ and $6.51 \mathrm{ppm}(\mathrm{s}, 1 \mathrm{H})$ for the proton bound to quinone ring.

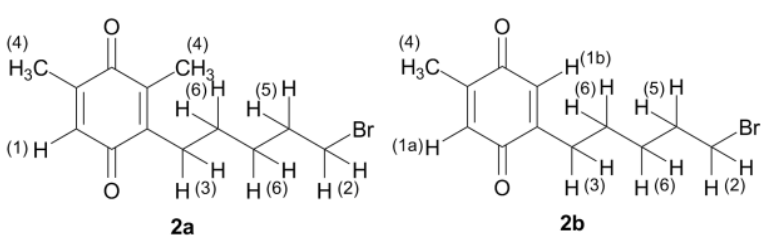

Figure 2. Structure of compound $\mathbf{2 a}$ and $\mathbf{2 b}$

Table 2. ${ }^{1} \mathrm{H}$ NMR spectral data for $\mathbf{2 a}$ and $\mathbf{2 b}$

\begin{tabular}{ccc}
\hline \multirow{2}{*}{ Proton } & \multicolumn{2}{c}{$\delta(\mathrm{ppm})$} \\
\cline { 2 - 3 } & $\mathbf{2 a}$ & $\mathbf{2 b}$ \\
\hline $1 \mathrm{a}$ & $6.54(\mathrm{~s}, 1 \mathrm{H})$ & $6.56(\mathrm{~s}, 1 \mathrm{H})$ \\
$1 \mathrm{~b}$ & - & $6.51(\mathrm{~s}, 1 \mathrm{H})$ \\
2 & $3.40(\mathrm{t}, 2 \mathrm{H}, J=6.8$ & $3.41(\mathrm{t}, 2 \mathrm{H}, J=6.8$ \\
$\mathrm{Hz})$ & $\mathrm{Hz})$ \\
& $2.46(\mathrm{t}, 2 \mathrm{H}, J=7.8$ & $2.45(\mathrm{t}, 2 \mathrm{H}, J=7.7$ \\
3 & $\mathrm{~Hz})$ & $\mathrm{Hz})$ \\
& $2.04(\mathrm{~s}, 6 \mathrm{H})$ & $2.05(\mathrm{~s}, 3 \mathrm{H})$ \\
4 & $1.87(\mathrm{q}, 2 \mathrm{H}, J=6.8 ;$ & $1.89(\mathrm{q}, 2 \mathrm{H}, J=6.8 ;$ \\
5 & $7.4 \mathrm{~Hz})$ & $7.7 \mathrm{~Hz})$ \\
& $1.45(\mathrm{~m}, 4 \mathrm{H}, J=7.4 ;$ & $1.50(\mathrm{~m}, 4 \mathrm{H}, J=7.7 ;$ \\
6 & $7.8 \mathrm{~Hz})$ & $6.8 \mathrm{~Hz})$
\end{tabular}

3.2. Solubility test of 2-(5-bromoamyl)-3,5-dimethyl1,4-benzoquinone (2a) and 2-(5-bromoamyl)-5methyl-1,4-benzoquinone (2b)

Solubility test of $\mathbf{2 a - b}$ was carried out using the HPLC method [13] and expressed by $\log$ P. The log P value can also be used to give recommendations for how the drug is administered in the body. If the synthesized compounds are relatively hydrophobic, the plasma membrane may be permeable, and the compound easily penetrates the membrane. The shake flask method was chosen to measure the solubility of compounds using noctanol and water (phosphate buffer $\mathrm{pH}$ 7.4) for the in vitro approach. At the same time, the marker of lipophilicity (hydrophobicity) refers to solubility compounds is also predicted using ALOGPS 2.1 program for the comparison [16]. In this study, the noctanol/water partition tested in a 3:7 $(\mathrm{v} / \mathrm{v})$ ratio. The concentration of the compound in each phase was measured using HPLC, and the ratio area was used to calculate the $\log P$ value (Tables 3 ).

Table 3. Calculated partition coefficient $(\log P)$ of compound $\mathbf{2 a}$ and $\mathbf{2 b}$ by HPLC analysis

\begin{tabular}{|c|c|c|c|c|}
\hline \multirow[t]{2}{*}{ Compound } & \multirow{2}{*}{$\begin{array}{c}\text { The area in } \\
\text { octanol } \\
\text { partition } \\
(\mathrm{Ao})^{\mathrm{a}}\end{array}$} & \multirow{2}{*}{$\begin{array}{l}\text { The area } \\
\text { in water } \\
\text { partition } \\
(\mathrm{Aw})^{\mathrm{a}}\end{array}$} & \multicolumn{2}{|r|}{$\log P$} \\
\hline & & & $\underset{\text { vitro }^{\text {a }}}{\text { In }}$ & Prediction ${ }^{\mathrm{b}}$ \\
\hline $2 a$ & 914422497 & 217331 & 2.99 & 3.21 \\
\hline $2 b$ & 1583466 & 210841 & 1.36 & 2.66 \\
\hline TQ & 93552748 & 927468 & 2.37 & 2.00 \\
\hline
\end{tabular}

a HPLC analysis

b Predicted using ALOGPS 2.1 


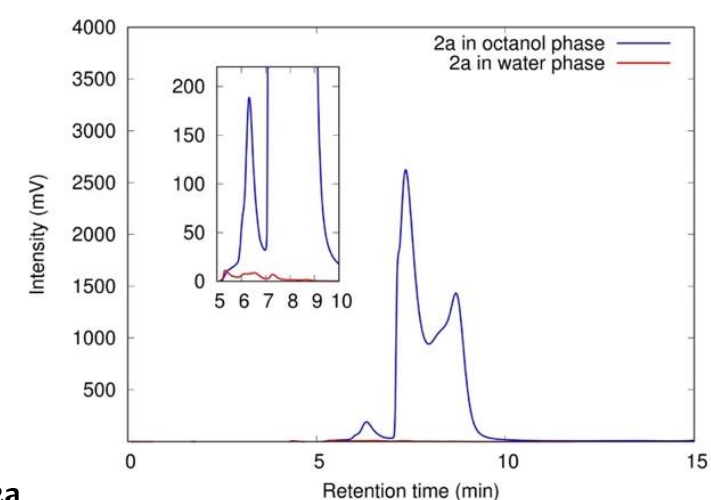

2a

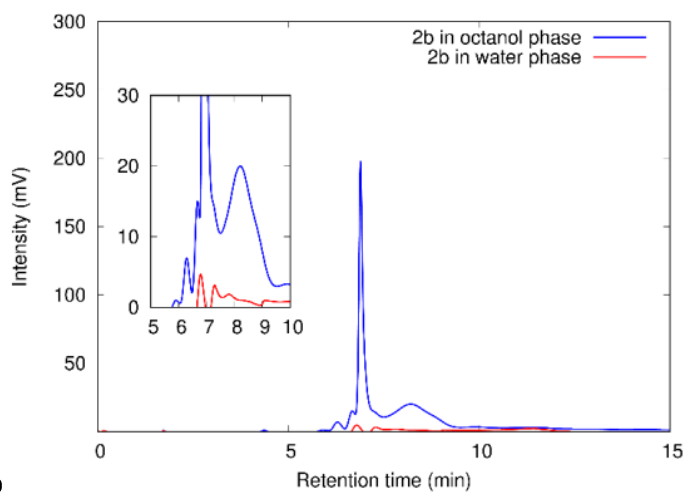

Figure 3. HPLC profile of compound $\mathbf{2 a}, \mathbf{2 b}$ in $\mathrm{n}$-octanol/water phase

In the chromatogram (Figure 3), it can be observed that the solubility of $\mathbf{2 a}$ and $\mathbf{2} \mathbf{b}$ in the octanol phase is greater than in the aqueous phase. It is showed that the hydrophobicity of compounds tends to be greater than the hydrophilicity. Furthermore, the log $\mathrm{P}$ value suggested that the hydrophobicity sequence is as follows, $\mathbf{2 a}>\mathbf{T Q}>\mathbf{2 b}$. Compound $\mathbf{2 a}$ gives $\log \mathrm{P}$ value 2.99, which is greater than $\mathbf{T Q}$ and $\mathbf{2 b}$. Based on the recommendations from Comer [17] and Triggle and Taylor [18], the $\log \mathrm{P}$ value of $\mathbf{2 a}$ is suitable for oral administration drugs. This compound can also penetrate the cell membrane through the intestinal tissue and distributed into the body by the central nervous system or other. However, the $\log \mathrm{P}$ value of compound $2 \mathrm{a}$ is at a low threshold. Based on this analysis, further effort should be attempted to modify the 1,4-benzoquinone by adjusting the number of alkyl substituents.

\section{Conclusion}

Compound $\mathbf{2 a}$ and $\mathbf{2 b}$ were synthesized in $\mathbf{1 3 . 7 5} \%$ and $4.04 \%$, respectively. The addition of alkyl substituent is analyzed by NMR. The presence of the bromoalkyl group in $\mathbf{2 a}$ and $\mathbf{2 b}$ was also detected using FTIR analysis. The presence of methyl substituent greatly influences the solubility of the compound almost 2-fold. The solubility test by in-vitro analysis using the HPLC approach was in accordance with calculation prediction.

\section{Acknowledgment}

Part of this research financially supported by the DPP/SPP research grant from DIPA of Faculty of Science, Brawijaya University, no. 18/UN10.F09.1/PN/2019.

\section{References}

[1] Chern Chiuh Woo, Alan Prem Kumar, Gautam Sethi and Kwong Huat Benny Tan, Thymoquinone: Potential cure for inflammatory disorders and cancer, Biochemical Pharmacology, 83, 4, (2012), 443451 https://doi.org/10.1016/j.bcp.2011.09.029

[2] Regine Schneider-Stock, Isabelle H. Fakhoury, Angela M. Zaki, Chirine O. El-Baba and Hala U. GaliMuhtasib, Thymoquinone: fifty years of success in the battle against cancer models, Drug Discovery Today, 19, 1, (2014), 18-30 https://doi.org/10.1016/j.drudis.2013.08.021

[3] Mohammad Rashidmayvan, Majid Mohammadshahi, Seyed Saeed Seyedian and Mohammad Hossein Haghighizadeh, The effect of Nigella sativa oil on serum levels of inflammatory markers, liver enzymes, lipid profile, insulin and fasting blood sugar in patients with non-alcoholic fatty liver, Journal of Diabetes \& Metabolic Disorders, 18, 2, (2019), 453-459

https://doi.org/10.1007/s40200-019-00439-6

[4] Mohammed Bule, Shekoufeh Nikfar, Mohsen Amini and Mohammad Abdollahi, The antidiabetic effect of thymoquinone: A systematic review and metaanalysis of animal studies, Food Research International, 127, (2020), 108736

https://doi.org/10.1016/j.foodres.2019.108736

[5] Khalid M. Alkharfy, Ajaz Ahmad, Rao M. A. Khan and Waleed M. Al-Shagha, Pharmacokinetic plasma behaviors of intravenous and oral bioavailability of thymoquinone in a rabbit model, European Journal of Drug Metabolism and Pharmacokinetics, 40, 3, (2015), 319-323 https://doi.org/10.1007/s13318-014-0207-8

[6] Okiemute Rosa Johnson-Ajinwo, Imran Ullah, Haddijatou Mbye, Alan Richardson, Paul Horrocks and Wen-Wu Li, The synthesis and evaluation of thymoquinone analogues as anti-ovarian cancer and antimalarial agents, Bioorganic \& Medicinal Chemistry Letters, 28, 7, (2018), 1219-1222 https://doi.org/10.1016/j.bmcl.2018.02.051

[7] Fath Dwisari, Arie Srihardyastutie and Siti Mariyah Ulfa, Synthesis of 2-methyl-5-methoxy-1,4benzoquinone and In-silico Activity Profiling Toward Cytochrome P450-3A4, IOP Conference Series: Materials Science and Engineering, 546, (2019), $062005 \quad$ http://dx.doi.org/10.1088/1757899X/546/6/062005

[8] Andriani Furoida and Siti Mariyah Ulfa, Synthesis of 3-(7-triphenylphosphonioheptyl)-2,6-dimethyl1,4-benzoquinone) and The Activity Test Toward Glycogen Phosphorylase Enzyme: In silico Approach, IOP Conference Series: Materials Science and Engineering, 546, (2019), 062008

http://dx.doi.org/10.1088/1757-899X/546/6/062008

[9] Novia Eka Setyatama, Siti Mariyah Ulfa and Hideki Okamoto, Synthesis and Activity Analysis of 3-(10Bromodecyl)-5-isopropyl-2-methyl-1,4benzoquinone: In-silico Approach, 1st International Conference in One Health (ICOH 2017), (2017) https://doi.org/10.2991/icoh-17.2018.24

[10] Christopher A. Lipinski, Franco Lombardo, Beryl W. Dominy and Paul J. Feeney, Experimental and computational approaches to estimate solubility and permeability in drug discovery and development settings, Advanced Drug Delivery Reviews, 46, 1, 
(2001), 3-26

https://doi.org/10.1016/S0169-409X(00)00129-0

[11] Y. N. Antonenko, A. V. Avetisyan, L. E. Bakeeva, B. V. Chernyak, V. A. Chertkov, L. V. Domnina, O. Yu Ivanova, D. S. Izyumov, L. S. Khailova, S. S. Klishin, G. A. Korshunova, K. G. Lyamzaev, M. S. Muntyan, O. K. Nepryakhina, A. A. Pashkovskaya, O. Yu Pletjushkina, A. V. Pustovidko, V. A. Roginsky, T. I. Rokitskaya, E. K. Ruuge, V. B. Saprunova, I. I. Severina, R. A. Simonyan, I. V. Skulachev, M. V. Skulachev, N. V. Sumbatyan, I. V. Sviryaeva, V. N. Tashlitsky, J. M. Vassiliev, M. Yu Vyssokikh, L. S. Yaguzhinsky, A. A. Zamyatnin and V. P. Skulachev, Mitochondria-targeted plastoquinone derivatives as tools to interrupt execution of the aging program. 1. Cationic plastoquinone derivatives: Synthesis and in vitro studies, Biochemistry (Moscow), 73, 12, (2008), 1273-1287 https://doi.org/10.1134/S0006297908120018

[12] Siti Mariyah Ulfa, Shoimatus Sholikhah and Edi Priyo Utomo, Synthesis of Thymoquinone derivatives and its activity analysis: In-silico approach, AIP Conference Proceedings, (2017) https://doi.org/10.1063/1.4978175

[13] Axel Andrés, Martí Rosés, Clara Ràfols, Elisabeth Bosch, Sonia Espinosa, Víctor Segarra and Josep M. Huerta, Setup and validation of shake-flask procedures for the determination of partition coefficients $(\log \mathrm{D})$ from low drug amounts, European Journal of Pharmaceutical Sciences, 76, (2015), 181-191 https://doi.org/10.1016/j.ejps.2015.05.008

[14] Wilbes Mbiya, Itai Chipinda, Paul D. Siegel, Morgen Mhike and Reuben H. Simoyi, Substituent Effects on the Reactivity of Benzoquinone Derivatives with Thiols, Chemical Research in Toxicology, 26, 1, (2013), 112-123 https://doi.org/10.1021/tx300417z

[15] Donald L. Pavia, Gary M. Lampman, George S. Kriz and James A. Vyvyan, Introduction to Spectroscopy, Cengage Learning, 2008

[16] Igor V. Tetko and Vsevolod Yu Tanchuk, Application of Associative Neural Networks for Prediction of Lipophilicity in ALOGPS 2.1 Program, Journal of Chemical Information and Computer Sciences, 42, 5, (2002), 1136-1145 https://doi.org/10.1021/ci025515j

[17] John E. A. Comer, High-Throughput Measurement of $\log \mathrm{D}$ and pKa, in: Drug bioavailability: Estimation of solubility, permeability, absorption and bioavailability, 2003, pp. 21-45 https://doi.org/10.1002/3527601473.ch2

[18] David J. Triggle and John B. Taylor, Comprehensive Medicinal Chemistry II, Elsevier Science, 2006 


\section{Supplementary}

Supplementary 1 (S1a)

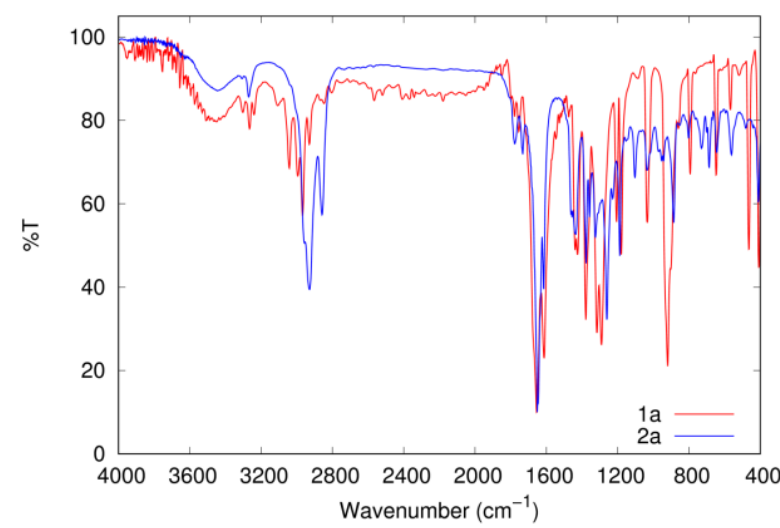

Figure S1a. FTIR spectra of starting material 2,6dimethyl-1,4-benzoquinone (1a) dan synthesized product 2-(5-bromoamyl)-3,5-dimethyl-1,4benzoquinone (2a)

\section{Supplementary 1 (S1b)}

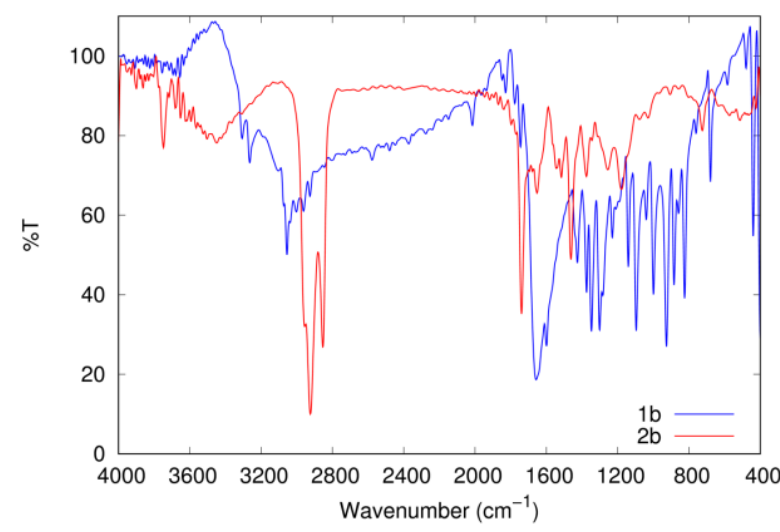

Figure S1b. FTIR spectra of starting material 2-methyl1,4-benzoquinone (1b) dan synthesized product 2-(5bromoamyl)-5-methyl-1,4-benzoquinone (2b)

\section{Supplementary 2 (S2a)}

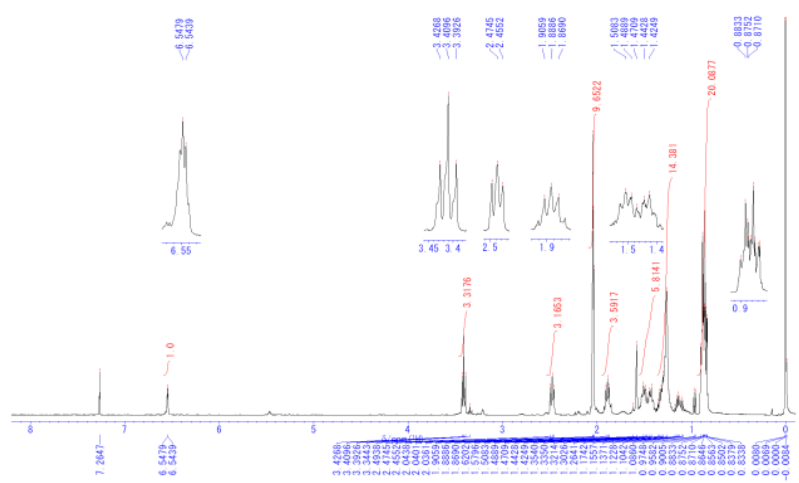

Figure S2a. ${ }^{1} \mathrm{H}-\mathrm{NMR}$ spectra of the synthesized product 2-(5-bromoamyl)-3,5-dimethyl-1,4-benzoquinone (2a) in $\mathrm{CDCl}_{3}$ recorded at JEOL ECS $400 \mathrm{MHz}$

\section{Supplementary 2 (S2b)}

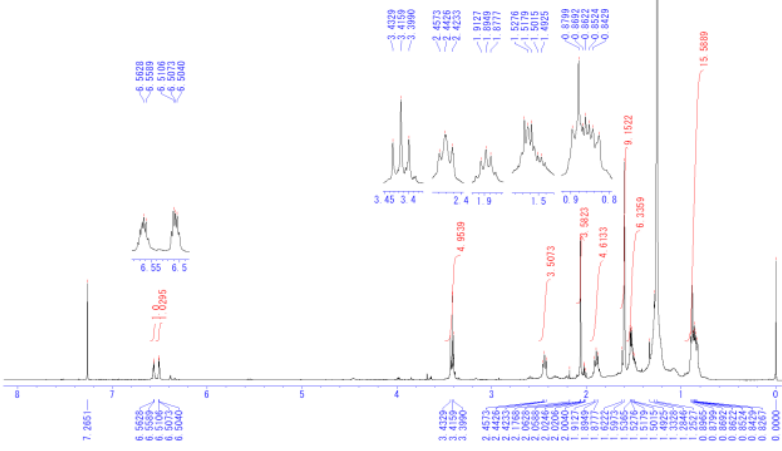

Figure S2b. ${ }^{1} \mathrm{H}-\mathrm{NMR}$ spectra of the synthesized product 2-(5-bromoamyl)-5-methyl-1,4-benzoquinone (2b) in $\mathrm{CDCl}_{3}$ recorded at JEOL ECS $400 \mathrm{MHz}$. 